\title{
ANALISIS WACANA BLACK CAMPAIGN (KAMPANYE HITAM) \\ PADA PILPRES TAHUN 2014 \\ DI MEDIA KOMPAS, JAWA POS DAN KEDAULATAN RAKYAT
}

\author{
La Januru ${ }^{1}$
}

\begin{abstract}
This thesis discusses black campaign discourse analysis (smear campaign) in the 2014 presidential election in the three media such as Kompas, Jawa Pos, and Sovereignty of the People. Discourse analysis in three media smear campaign by using the theory of critical discourse analysis (CDA) of Norman Fairclough. Research method in this research was discourse analysis. The study concluded that the practice of black campaign in the 2014 presidential election occurred in very high intensity, especially mediated-media both print and electronic media. It can be seen from the following indicators: first, the unhealthy campaign or unproductive as to demonize the other candidates. Second, the advertisement certainly has a tendency to attack (political attacks). Third, these ads do not have a clear source. Thus it can be said that these advertisement were problematic from any perspective. The messages in these ads were very provoking and does not give a good political education for the public.
\end{abstract}

Keywords: Black Campain and Media.

\begin{abstract}
ABSTRAK
Tesis ini membahas analisis wacana black campaign (kampanye hitam) pada pilpres tahun 2014 di tiga media seperti Kompas, Jawa Pos, dan Kedaulatan Rakyat. Analisis wacana kampanye hitam di tiga media ini dengan menggunakan teori Critical discourse analysis (CDA) dari Norman Fairclough. Metode yang digunakaAn dalam penelitian ini adalah metode analisis wacana. Hasil penelitian menyimpulkan bahwa praktik black campaign pada pilpres 2014 terjadi dengan intensitas yang sangat tinggi, terutama dimedia-media baik cetak maupun media elektronik. Hal ini dapat dilihat dari indicator berikut ini: pertama, kampanye yang tidak sehat atau tidak produktif seperti menjelek-jelekan calon lain. Kedua, iklan tersebut sudah pasti mempunyai tendensi menyerang (serangan politik). Ketiga, iklan tersebut tidak mempunyai sumber yang jelas. Dengan demikian bisa dikatakan iklan tersebut bermasalah dilihat dari sudut pandang apapun.Termasuk pesan yang ada dalam iklan tersebut sangat memprovokasi dan tidak memberikan pendidikan politik yang baik bagi publik.
\end{abstract}

Kata kunci: Black Campain dan Media.

1 Pascasarjana Ilmu Pemerintahan Universitas Muhammadiyah Yogyakarta. email: janu.gempar@yahoo.com 


\section{PENDAHULUAN}

Salah satu ukuran pemilu disebut sebagai proses demokrasi yang ideal, dan efektif adalah rakyat secara langsung dapat memilih wakil-wakilnya yang duduk di eksekutif maupun Legislatif. Hal ini paralel dengan konsep modern tentang demokrasi ala Joseph Shumpeter (mazhab Shumpeterian) yang menempatkan penyelenggaraan pemilu yang bebas dan berkala sebagai kriteria utama bagi suatu system politik untuk dapat disebut demokrasi (Najib, 2014). Begitu pentingnya pemilu dalam perjalanan sebuah Negara sehingga semua Negara menjadikan ajang tersebut sebagai mekanisme pergantian kekuasaan yang tertib sekaligus sebagai syarat Negara tersebut diklaim sebagai Negara demokratis.

Dari sekian banyak Negara-negara yang telah menyelenggarakan pemilu, paling tidak terdapat tiga kelompok Negara penyelenggara pemilu, yakni : pertama, Negara-negara liberal demokratis, yaitu Negara-negara yang melaksanakan pemilu dengan kebebasan penuh warga Negara untuk menggunakan hak pilihnya secara mutlak serta pemilu yang diselenggarakan terlaksana secara free and fair sesuai standar dan prinsip pemilu universal. Kedua, Negara-negara electoral democracy, yakni Negara-negara yang menyelenggarakan pemilu namun hanya memberikan hak politik warga secara terbatas dan pemilu yang diselenggarakan belum sepenuhnya berlangsung secara free and fair. Ketiga, Negara-negara electoral autokratis, yakni Negara-negara yang menyelenggarakan pemilu, namun pemilu yang dilaksanakan sekedar dijadikan alat bagi penguasa yang autokratis sebagai sarana untuk melestarikan kekuasaan yang ingin dipertahankan oleh rezim yang sedang berkuasa.

Pelaksanaan pemilu di Indonesia harus diakui masih diwarnai dengan berbagai masalah sehingga memungkinkan muncul angapan bahwa Indonesia sebagai Negara yang sudah melaksanakan pemilu, namun masih dalam tahap pemilu-pemiluan. Sebuah proses pemilu yang belum sesuai dengan standar dan prinsip-prinsip pemilu Universal (Setiadi, 2013). Situasi pemilu di Indonesia dari pemilu ke pemilu praktik pragmatisme selalu saja terjadi. Hal ini bisa dilihat dari statemen-statemen politik para elit dalam momen kampanye politik. Dalam konteks strategi politik, tentu saja kampanye politik itu adalah suatu keharusan, selama didalamnya tidak 
melanggar aturan-aturan sebagaimana tercover dalam Undang-Undang. Seperti praktik black campaign, money politic dan strategi-strategi busuk lainya (Setiadi, 2013).

Dalam tiga kali pemilu pasca reformasi terjadi penurunan cukup signifikan tingkat partisipasi dari pemilu kepemilu berikutnya, misalnya pada pemilu tahun 1999 tingkat partisipasi mencapai $94 \%$, dan pemilu tahun 2004 turun menjadi $92 \%$, selanjutnya pemilu 2009 turun lagi menjadi $71 \%$ (Najib, 2014). Kondisi ini kemudian, menimbulkan kekhawatiran akan terjun bebas tingkat partisipasi rakyat dalam pemilu 2014 bahkan dibawah 50\%. Menurunya partisipasi pemilih dalam pemilu akan mempengaruhi maksimalnya pelaksanaan pemilu. Selain itu, tentu berimplikasi pada rendahnya partisipasi public untuk bersedia ikut mengawasi seluruh tahapan pemilu dan sekaligus bersedia melaporkan pada pengawas pemilu jika ditemukan indikasi adanya pelanggaran pemilu.

Masalah lain yang sering ditemui dalam setiap event pemilu presiden, yakni masalah Black Campaign. Hal ini misalnya bisa ditelusuri dalam pemilu tahun 2014, yang ruangnya, yaitu media
(Najib, 2014). Berdasarkan hasil studi dokumentasi awal penulis di beberapa media cetak dan elektronik dapat diketahui bahwa aktivitas black campaign yang ditujukan kepada pasangan Prabowo-Hatta ini berkaitan dengan isu pelanggaran HAM (Hak Asasi Manusia) yang dilakukan oleh Prabowo Subianto selaku Danjen Kopasus pada tahun 1998 yang membuat beberapa aktivis HAM diculik dan meninggal dunia. Aktivis HAM tersebut pada tahun 1998 sampai dengan saat ini tidak diketahui keberadaannya dan tidak ada penyelesaian secara hukum sampai pada saat ini.

Hasil dari aktivitas black campaign (kampanye hitam) tersebut berdampak pada penurunan jumlah suara pada pasangan Prabowo-Hatta. Hasil pada pemilu Presiden dan Wakil Presiden 2014 yang diadakan pada 9 Juli 2014 yang lalu dapat diketahui bahwa pasangan PrabowoHatta secara nasional memperoleh suara yang lebih rendah dibandingkan dengan pasangan Jokowi-JK. Hal tersebut seperti yang terjadi di wilayah Kabupaten Sleman, dimana suara dari pasangan Prabowo-Hatta kalah dibandingkan dengan pasangan Jokowi-JK.

Kampanye hitam juga terjadi pada Jokowi-JK, berbagai berita dimedia sangat 
intens memberitakan hal tersebut. Ini menunjukan bahwa masa kampanye pilpres tahun 2014 diisi dengan maraknya black campaign (kampanye hitam) yang menyerang masing-masing kandidat. Baik Jokowi-JK maupun Prabowo-Hatta.

Pertama, Jokowi diserang dengan tulisan yang dimuat di tabloid obor rakyat. Pada edisi pertama, 5-11 Mei 2014, halaman muka tabloid obor rakyat menampilkan judul Capres Boneka dengan karikatur Jokowi sedang mencium tangan Megawati Sukarnoputri. Tabloid itu juga menampilkan 14 berita panjang yang hampir semuanya menyudutkan Jokowi. Beberapa judul berita dalam tabloid ini antara lain, Capres Boneka Suka Ingkar Janji, Disandera Cukong dan Misionaris, Dari Solo Sampai Jakarta Deislamisasi ala Jokowi, Manuver Jacob Soetojo, Cukong-Cukong di Belakang Jokowi, Partai Salib Pengusung Jokowi"dan Jokowi Juru Selamat yang Gagal. Kedua, sebelum diserang melalui tabloid Obor Rakyat, Jokowi lebih dulu diserang dengan isu keturunan Tionghoa dan agama Kristen. Jokowi disebut sebagai keturunan Cina yang bernama Wie Jo Koh. Isu ini bermula dari tulisan artikel jurnalisme warga yang ditulis Anton Surya pada 19 Desember 2012.
Namun, memasuki masa kampanye pilpres, tulisan tersebut dikutip dan digunakan tanpa menyertakan penjelasan aslinpya. Terkait isu agama, Jokowi sempat diberitakan memiliki nama lengkap Heribertus Joko Widodo. Ketiga, tak hanya dpiserang melalui SARA, Jokowi Juga diserang dengan isu buku nikah palsu. Untuk menepis isu itu, tim ppemenangan Jokowi-JK bahkan mengeluarkan fotokopi surat nikah Jokowi.

Berdasarkan pemaparan di atas, penulis tertarik untuk menganalisis lebih dalam mengenai analisis wacana black campaign (kampanye hitam) pada pilpres tahun 2014 di media Kompas, Jawa Pos, dan Kedaulatan Rakyat. Adapun alasan penulis memilih judul penelitian yang saat ini sedang penulis dalami, yakni: pertama, adanya keyakinan bahwa Pemilu satusatunya jalan procedural bagi rakyat untuk menentukan pilihan atau aspirasi politiknya. Selain itu, pemilu juga merupakan alternative bagi Negara dalam membagun iklim demokratisasi serta sarana penyaluran kedaulatan rakyat. Kedua, Pemilu juga sebagai momentum bagi masyarakat dalam memahami proses politik sekaligus terlibat dalam pendidikan politik yang mendewasakan sikap politik masyarakat. Dipilihnya Kompas, Jawa 
Pos, dan Kedaulatan Rakyat sebagai objek kajian dalam tulisan ini, sebab tiga media ini merupakan media Nasional yang secara esensial dianggap sebagai media yang sudah mafan. Kompas mewakili aspirasi masyarakat Jakarta dan sekitarnya, Jawa Pos mewakili aspirasi masyarakat Jawa Timur dan masyarakat Indonesia bagian Timur, dan Kedaulatan Rakyat mewakili aspirasi masyarakat Jawa Tengah.

Dalam teori politik kampanye hitam mempengaruhi pada peningkatan kesadaran kritis pemilih dan cenderung propokatif. Secara normatif istilah kampanye hitam (black campaign) tidak dikenal dalam paket Undang-Undang pemilu, tetapi pengertian tentang hal itu tersurat dalam beberapa ketentuannya.

Esensi kampanye hitam adalah upaya yang terorganisir bertujuan untuk mempengaruhi proses pengambilan keputusan para pemilih dengan menggunakan berbagai metode, misalnya rayuan yang merusak, sindiran atau rumors yang tersebar dengan sasaran para kandidat atau calon, sehingga menimbulkan persepsi negatif dimasyarakat serta fenomena sikap resistensi dari para pemilih (Najib, 2014). Menurut Riswandi, kampanye hitam (black campaign) merupakan model kampanye dengan menggunakan rayuan yang merusak, sindiran atau rumors yang tersebar mengenai sasaran kepada para kandidat atau calon kepada masyarakat agar menimbulkan presepsi yang dianggap tidak etis terutama dalam hal kebijakan public (Riswandi, 2009).

Sementara menurut Cagraha (2009) black campaign (kampanye hitam) dimaknai sebagai usaha untuk mengisi jabatan tertentu, terutama untuk jabatan publik dengan cara-cara yang tidak sehat (gossip). Kampanye hitam yang biasa disebut black campaign lanjut Haffied, cendrung menyudutkan para calon yang diusung untuk menduduki suatu jabatan. Kampanye hitam umumnya dapat dilakukan oleh kandidat atau calon bahkan pihak lain secara efisien karena kekurangan sumber daya yang kuat untuk menyerang salah satu kandidat atau calon lain dengan bermain pada permainan emosi para pemilih agar pada akhirnya dapat meninggalkan kandidat atau calon pilihannya (Firmanzah, 2013)

Menurut Charles U. Larson dalam (Ruslan, 2007) dalam bukunya yang berjudul Persuasion, Reception and Responsibility, telah membagi kampanye menjadi beberapa jenis antara lain: 
product oriented campaign, candidate oriented campaign, ideological or causeoriented campaign. Jika dirunut dengan lebih dalam bahwa hasil dari sebuah kampanye baik itu kampanye positif maupun kampanye negative atau pun kampanye hitam ini merupakan buah dari interaksi setiap individu dalam proses politik yang sedang berjalan. Kontakkontak antar sub budaya politik memungkinkan timbulnya interaksi. Pada dasarnya, interaksi tersebut merupakan suatu proses pengembangan budaya politik (Wijaya, 2010). Proses seperti ini oleh Hikmat disebutnya sebagai sosialisasi politik, yaitu suatu proses dimana anggota masyarakat mengalami, menyerap, dan menghayati nilai-nilai yang ada disekitarnya. Melalui proses itulah, budaya politik tumbuh dan berkembang dalam masyarakat (Hikmat, 2011).

Kampanye jenis ini biasanya sulit untuk diverifikasi apalagi diperdebatkan. Untuk melihat contoh kongkrit dari kampanye hitam yang menyerang dua calon presiden pada pilpres tahun 2014 baik yang menyerang Jokowi-JK maupun Prabowo-Hatta Rajasa.
Table 1. Kampanye Hitam Yang Menyerang Calon Presiden No. Urut 1 Prabowo-Hatta Rajasa dan No. Urut 2 Jokowidodo Yusuf Kalla

\begin{tabular}{|c|c|}
\hline $\begin{array}{l}\text { lye Hitam } \\
\text { n ke Prabowo }\end{array}$ & 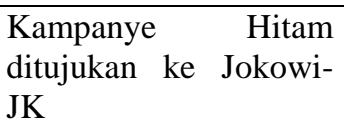 \\
\hline 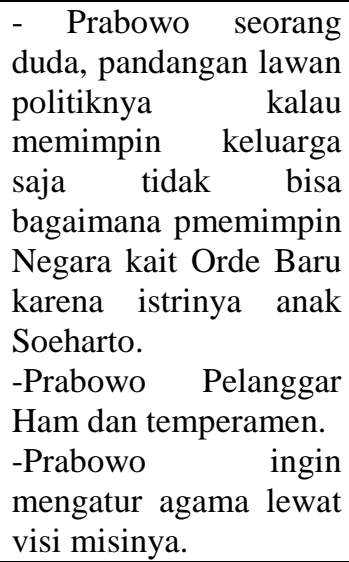 & $\begin{array}{l}\text { - JK berkata } \\
\text { bisa hegara } \\
\text { dipimpin Jokowi. } \\
\text { - Jokowi Boneka } \\
\text { Megawati. } \\
\text { - Jokowi Disandra } \\
\text { Cukong/pro Asing. } \\
\text { - Jokowi Keturunan } \\
\text { Tiong Hoa. }\end{array}$ \\
\hline
\end{tabular}

Sumber: Cleveland Ferguson, The Politics of ethics and elections : CanNegatifve Campaign Advertising Be Regulated In Florida?. melalui: http//www.law.fsu.edu/journal/lawreview/frames/2 42/fergfarm.html, diakses 13 Mei 2016.

Tinjauan lain dari jenis kampanye hitam ini bisa dilihat dari pembagian jenis kampanye yang ditentukan oleh Sunandar adalah kampanye yang menjelekkan pihak lawan namun data dan faktanya masih abu-abu. Benar atau salahnya belum bisa dibuktikan.Cuma dikesankan bahwa pihak lawan politik adalah salah (Sunandar, 2013). Contohnya adalah sebagai berikut:

1. Prabowo diduga menculik dan melanggar HAM ditahun 1998.

2. Prabowo pindah kewarganegaraan Yordania.

3. Jokowi diduga terlibat korupsi Trans Jakarta.

4. Jokowi gagal memimpin Jakarta. 
Secara umum bentuk kampanye hitam adalah menyebarkan keburukan atau kejelekan seorang politikus dengan tujuan (Piliang, 2005):

1. Menjatuhkan nama baik seorang politikus sehingga dia menjadi tidak disenangi teman-teman separtainya, khalayak pendukungnya dan masyarakat umum.

2. Menjatuhkan nama baik seorang politikus dengan tujuan menjatuhkan nama baik parpol tempat elit/politikus tersebut berkarir, yang berefek kepada politikus-politikus lain di parpol tersebut atau bahkan sekaligus menggagalkan calon presiden yang didukung parpol tersebut (efek domino).

Cara-cara yang dipakai dalam berkampanye hitam adalah (Hikmat, 2009):

1. Menyebarkan kejelekan atau keburukan tentang seorang politikus, dengan cara memunculkan cerita buruk dimasa lalunya, menyebarkan cerita yang berhubungan dengan kasus hokum yang sedang berlangsung, atau menyebarkan cerita bohong atau fitnah lainya.
2. Untuk mnguatkan cerita tersebut biasanya si penyebar cerita akan menyertakan berupa bukti foto. Foto-foto tersebut bisa saja benarbenar terjadi, tetapi bisa juga benarbenar terjadi tetapi tidak terkait langsung dengan permasalahan, namun si penyebar foto berharap asumsi masyarakat terbentuk atau bisa juga foto tersebut hasil rekayasa/manifulasi dengan bantuan tekhnologi kompuiter.

\section{METODE}

Pendekatan yang digunakan dalam penelitian ini adalah pendekatan analisis wacana. Analisis wacana menurut Eriyanto (2012) adalah studi mengenai bahasa atau studi mengenai pemakaian bahasa, dalam analaisis wacana dimaksudkan untuk menggambarkan tata aturan kalimat, bahasa, dan pengertian bersama sekaligus membongkar maksudmaksud dan makna-makna tertentu dalam kalimat/bahasa.

Metode analisis lain yang digunakan dalam penelitian ini adalah analisis wacana yang dipopulerkan oleh Mulyana (2005) yang mengatakan bahwa analisis wacana adalah analisis wacana, ini merujuk pada upaya mengkaji pengaturan bahasa di atas klausa dan kalimat, dan 
karenanya juga mengkaji satuan-satuan kebahasaan yang lebih luas. Seperti pertukaran percakapan atau bahasa tulis. Konsekuensinya, analisis wacana juga memperhatikan bahasa pada waktu digunakan dalam konteks social, khususnya interaksi antar penutur.

Adapun jenis data yang akan digunakan dalam penelitian ini, yakni:

1. Data primer adalah data-data atau sumber-sumber yang mengikat yang terdiri dari Tiga Koran, yaitu Kompas, Jawa Pos, dan Kedaulatan Rakyat.

2. Data sekunder adalah data yang berupa dokumen-dokumen resmi, buku-buku hasil penelitian yang berwujud laporan, buku harian dan lain-lain.

Teknik pengumpulan data yang digunakan dalam penelitian ini adalah mengunakan dokumentasi dan kepustakaan. Tekhnik dokumentasi adalah teknik yang dilakukan untuk mendapatkan dokumen. Yang dimaksud dokumen adalah setiap bahan yang tertulis Moleong (2007). Yang dimaksud dengan bahan tertulis dalam penelitian ini adalah beritaberita yang ada ditiga Media, yakni Kompas, Jawa Pos, dan Kedaulatan Rakyat yang berkaitan dengan kampanye hitam pada pilpres tahun 2014. Sedangkan tekhnik pengumpulan data yang lain, yakni menggunakan studi kepustakaan. Menurut Nasution dalam bukunya "Metode Research" mengemukakan bahwa yang dimaksud dengan studi kepustakaan adalah tekhnik pengumpulan data dengan mengadakan studi penelaahan terhadap buku-buku, literatur-literatur, catatan-catatan, dan laporan-laporan yang ada hubunganya dengan masalah yang akan dipecahkan atau diteliti (Nasution, 2009).

Teknik analisis data dalam penelitian ini adalah menggunakan analisis wacana kritis (Critical Discourse Analisis/CDA). Menurut Eriyanto (2007), yang dimaksud dengan analisis wacana kritis adalah analisis wacana kritis adalah pola pengelolaan data dengan menggunakan bahasa dalam teks untuk dianalisis, tetapi bahasa yang dianalisis disini agak berbeda dengan studi bahasa dalam pengertian linguistic tradisional. Bahasa dianalisis bukan dengan menggambarkan semata dari aspek kebahasaan, tetapi juga menghubungkan dengan konteks. Konteks disini berarti bahasa itu dipakai untuk tujuan dan praktik tertentu, termasuk didalamnya praktik kekuasaan (Eriyanto, 2009). 


\section{HASIL DAN PEMBAHASAN}

Mengingat metode yang digunakan dalam penelitian ini menggunakan analisis wacana, maka analisis wacana dalam penelitian ini terpokus pada isi berita ditiga media, yakni Kompas, Jawa Pos, dan Kedaulatan Rakyat. Teks berita ditiga media tersebut berkaitan dengan kampanye hitam yang dibentuk lewat suatu praktik diskursus yang menentukan bagaimana teks tersebut dibentuk yang selanjutnya proses produksi teks dan konsumsi teks tersebut membentuk wacana (Eriyanto, 2001).

\section{Bentuk-bentuk kampanye hitam yang} terjadi dalam pilpres tahun 2014

Praktik kampanye hitam yang terjadi pada pilpres tahun 2014 terjadi ditiga media yang menjadi objek penelitian dalam penelitian ini. Kampanye hitam tersebut terjadi melalui saluran berita, opini, percakapan, gambar/simbol, yang dimuat oleh Kompas, Jawa Pos, dan Kedaulatan Rakyat. Adapun bentuk kampanye hitam yang mewarnai jalanya tahapan pilpres tahun 2014 ini bisa dilihat dari pembagian kampanye yang ditetapkan Sunandar adalah kampanye yang menjelekkan pihak lawan namun data dan faktanya masih abu-abu. Benar atau salahnya belum bisa dibuktikan.Cuma dikesankan bahwa pihak lawan politik adalah salah (Sunandar, 2013).

Untuk lebih jelasnya dapat dilihat dalam tabel berikut ini :

Tabel 2 Jenis Kampanye Hitam yang Menyerang Prabowo-Hatta Rajasa Dan Jokowi-JK

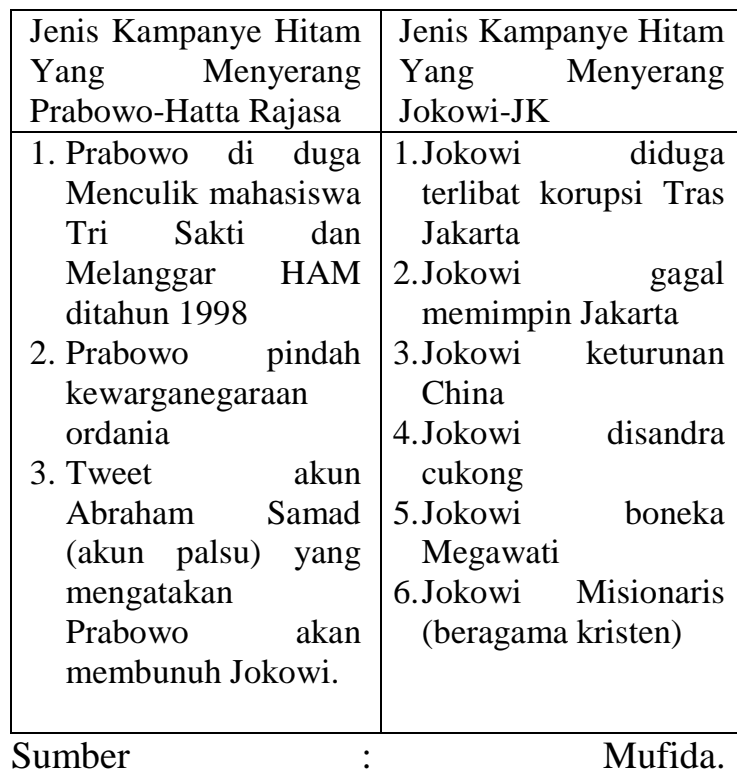

http://www.satuislam.org/opini/pengaruhkampanye-hitam-dan-pencitraan-politikdalam-pemilu-di-indonesia, data diolah.

Tabel di atas menegaskan bentukbentuk kampanye hitam dan kampanye abu-abu, yang mewarnai jalanya pilpres tahun 2014. Berita atau opini yang dimuat media pada dasarnya antara kebenaran dan opini cenderung kuat opininya. Maka untuk perkara ini, belum bisa dibuktikan benar dan salahnya. Berbeda dengan kampanye negatif yang sudah sangat terlihat data dan faktanya dilapangan. Kampanye hitam dalam pelaksanaanya mengarah ke pembunuhan karakter dan 
cenderung fitnah, kebohongan dan tuduhan tanpa bukti. Kampanye jenis inilah yang bisa dijerat hukuman, minimal dapat sanksi dari KPU jika tim capres melakukan kampanye ini.

Secara teoritis jenis kampanye hitam bisa diamati dari motivasi pelaku kampanye sebagaimana pembagian kampanye yang ditetapkan Charles U. Larson dalam (Ruslan, 2007) melalui bukunya yang berjudul Persuasion, Reception and Responsibility, telah membagi kampanye menjadi beberapa jenis antara lain:

\section{Product Oriented Campaigns,} adalah jenis kampanye yang berorientasi pada produk. Adapun motivasi yang mendasarinya adalah memperoleh keuntungan finansial. Cara yang ditempuh adalah dengan memperkenalkan produk atau melipat gandakan penjualan sehingga memperoleh keuntungan yang diharapkan.

2. Candidate Oriented Campaigns, adalah wkampanye yang berorientasi pada kandidat. Motivasinya adalah untuk mengarahi kekuasaan politik. Tujuan dari kampanye ini adalah untuk memenangkan dukungan dari masyarakat terhadap kandidatkandidat yang diajukan oleh partai politik agar mendapat jabatan yang diperebutkan melalui pemilihan umum. Kampanye jenis ini juga dapat disebut sebagai political campaign.

3. Ideological or Cause - Oriented Campaigns, adalah kampanye yang berorientasi pada tujuan yang bersifat khusus dan seringkali berdimensi perubahan social. Dalam pemasaran sosial kegiatan yang dilakukan umumnya berupa kampanye yang di dalamnya berisikan mengenai pesan-pesan yang ditujukan untuk khalayak biasanya berorientasi pada tujuan yang bersifat khusus dan seringkali berdimensi pada perubahan sosial. Dalam kampanye jenis ini, Kottler sebagaimana dikutif Venus (2007) menyebutnya dengan istilah social change campaigns, yaitu kampanye yang ditujukan untuk menangani masalah - masalah sosial bersifat non-komersial, seperti penanganan konflik saat masa kampanye.

Jenis kampanye model ini, dalam istilah Mage menyebutnya sebagai praktik kampanye masa bodoh. Fenomena 
kampanye seperti ini untuk konteks pemilu tahun 2014 sangat subur, seperti fenomena munculnya sikap apatisme politik, suatu sikap (masa bodoh diantara para elit).

\section{Dampak Kampanye Hitam terhadap Pemilih dalam Pilpres Tahun 2014.}

Sekejam apapun kampanye hitam dalam proses politik tetap cara tersebut selalu digunakan. Karena itu, kampanye hitam bisa dikatakan sebagai keniscayaan negative dari kehidupan demokratis (Irwan, 2014). Salah satu bentuk sederhana dari tirani demokrasi yaitu tirani popularitas yang mengacu pada penekanan berlebihan pada aspek citra sehingga kinerja dinomor sekiankan, terutama pada saat pemilu (Hargens, 2013).

Popularitas diutamakan sedemikian rupa sehingga implementasi politik hanyalah sebuah aksi tebar pesona. Akibatnya muncul kekhawatiran apakah proses politik yang berlangsung mampu dan bermutu dan tidak membuat pemilih salah pilih. Kampanye hitam termasuk pencitraan politik hanya akan membuat elit populer mudah melenggang masuk kelembaga Negara dari pada mereka yang benar-benar mampu dan bermutu. Sebagai contoh kasus kampanye hitam yang berkaitan dengan pencitraan politik terjadi saat setelah calon nomor urut 2 dinyatakan tertinggi surveinya pada Jumat, 11 Mei 2013. Diduga, simpatisan bakal pasangan calon merusak suasana kondusif Jakarta menjadi berpotensi konflik. Suasana panas terbentuk setelah munculnya rentetan peristiwa pembakaran Posko Pemenangan Jokowi-JK (Arwansyah, 2014). Kajian empiris di negara dengan kehidupan demokrasi yang matang menunjukkan bahwa kampanye negatif itu tidak efektif dalam meningkatkan elektabilitas calon yang didukung atau menekan elektabilitas calon lawan.Bagaimana dalam konteks Pilpres tahun 2014 di Indonesia?

Dampak kampanye hitam yang terjadi pada pilpres tahun 2014, paling tidak bisa dilihat dari penurunan elektabilitas calon dari dua pasangan antara Jokowi-JK dan Prabowo-Hatta Rajasa.Pada Juni 2014 Jokowi mendapat $30 \%$ lebih banyak dukungan dari pada Prabowo yang hanya mendapat $20 \%$. Setelah pada penghujung bulan Juni tepatnya awal Juli elektabilitas kedua pasangan calon selisihnya semakin ketat.Bahkan Prabowo sudah mengungguli Jokowi, situasi ini terjadi setelah desas-desus kampanye mulai gencar dilakukan kedua pendukung 
pasangan calon presiden. Salah satu isu yang dimainkan yang kemudian berdampak pada merosotnya citra dari dua pasangan calon presiden, yaitu pertama, isu yang menyerang Joko Widodo (Jokowi) dituduh beragama Kristen dan berasal dari etnis Cina.Seolah belum puas dengan itu semua, serangan berikutnya terhadap kubu Jokowi-Jusuf Kalla, seorang petinggi partai Gerindra dikolom Jawa Pos mengatakan, Jokowi adalah komunis. Kampanye "hitam" juga dilancarkan terhadap kubu Prabowo-Hatta Rajasa. Prabowo pernah dikatakan psikopat.Dalam sebuah video yang disebar lewat YouTube, yang mungkin sudah dimanipulasi, ditunjukkan bagaimana Prabowo yang terkenal pemarah memukul seseorang pada saat kampanye.Sebagian besar tuduhan atas kedua capres sudah disangkal, dan terbukti tuduhan memang tidak benar.

Dalam survey yang diadakan Indikator Politik Indonesia, 17\% dari 3.000 responden mengatakan telah mendengar desas-desus bahwa Jokowi keturunan Cina dan Kristen.Dan 37\% dari mereka yang mendengar desas-desus itu menyatakan percaya. Pilpres tahun 2014 yang sudah dilaksanakan apabila didekati dengan menggunakan pendekatan teori bounded rationality dalam perilaku memilih, kita bisa memprediksi bahwa efektivitas "kampanye hitam" dalam konteks pilpres tahun 2014 sangat masif. Bounded rationality adalah teori tentang perilaku manusia yang memilih karena dihadapkan pada keterbatasan kognitif, khususnya karena keterbatasan informasi tentang hal yang akan dipilih.

Faktor yang menentukan adalah apa yang dinamakan dengan perilaku heuristics. Dalam konteks bounded rationality, kampanye hitam dilakukan untuk menghadirkan perilaku heuristic (menyelidiki sendiri), yang disebut dengan affect referral. Perilaku affect referral (rujukan pengaruh) terjadi ketika para pemilih memilih kandidat yang menurut mereka paling menarik secara emosionalSelain itu, terdapat pula istilah familiarity (keakraban), di mana pemilih merasa ada kesamaan atau hubungan yang akrab dengan kandidat karena perilaku kandidat yang dinilai identik dengan mereka. Seorang calon presiden yang mampu menghadirkan jenis heuristic ini di kalangan pemilihnya juga akan imun terhadap kampanye hitam. Artinya, jika pemilih sebelum terjadi black campaign sudah menetapkan pilihanya atau sudah simpati dengan tokoh atau calon tertentu, maka sudah pasti akan membuat pemilih 
jadi panic, depresi dan bukan tidak mungkin akan menuai konflik.

\section{SIMPULAN}

Berdasarkan pembahasan yang digali dalam bab sebelumnya, penulis menetapkan pembagian jenis kampanye yang hal tersebut merupakan kesimpulan dalam penelitian ini.

Dampak kampanye hitam dalam pilpres tahun 2014 dapat dilihat dalam indicator berikut, yaitu pertama, menjatuhkan nama baik seorang calon presiden sehingga yang bersangkutan tidak disenangi oleh rekan separtainya, pendukungnya, dan masyarakat umum. Kedua, mematikan karakter calon presiden dengan mengungkap aib calon yang ada sehingga yang bersangkutan kehilangan simpatik. Selain itu kampanye hitam akan berdampak pada menurunya elektabilitas calon presiden yang bersaing dalam pilpres.

Menyimak hasil dari kesimpulan di atas, maka penulis mengajukan saran berupa rekomendasi sebagai berikut :

1. Institusi yang diberi mandate sebagai pelaksana pilpres seperti KPU, Bawaslu secara serius menegakan ketentuan pelaksanaan pemilu presiden (Undang-Undang Pemilu)
2. KPU dan Bawaslu secara konsisten menjalin kerja sama dengan semua elemen seperti media dan masyarakat untuk mengawal jalanya pelaksanaan tahapan kampanye pilpres.

3. Mempertegas adanya sangsi terhadap pihak yang melanggar ketentuan pilpres.

\section{DAFTAR PUSTAKA}

Andi Setiadi. 2013. Politik Harapan Palsu: Janji-janji politik yang tidak ditepati, Yogyakarta: IRCiSoD.

Albert Widjaja. 2010. Budaya Politik Dalam Perancangan Pendidikan Politik Jakarta : LP3ES.

Anwarsyah. 2014. Kampanye Hitam Dan Pendidikan Politik Bangsa, Jakarta: Rineka Cipta.

Eriyanto. 2012. Analisis Wacana: Pengantar Analisis Teks Media, Yogyakarta: LKiS.

Firmanzah. 2007. Marketing Politik. Jakarta: Yayasan Obor Indonesia.

Hafied Cagraha. 2009. Komunikasi Politik: konsep, teori, dan strategi, Jakarta : Rajawali Pers.

Hendra Sunandar. 2013. Regulasi Kampanye Pemilihan Umum 2014 Analisis Terhadap Aturan Main Kampanye Pemilu di Media Massa Jakarta: Fakultas Ilmu Sosial dan 
Ilmu Politik UIN Syarif Hidayatullah.

Lexy J. Moleong. 2007. Metodologi Penelitian Kualitatif. Bandung: Remaja Rosdakarya.

Mohammad Najib, dkk. 2014. Pengawasan Pemilu: Problem, \& Tantangan, Yogyakarta: Bawaslu Profinsi DIY.

Mulyana. 2005. Kajian Wacana: teori, metode \& Aplikasi prinsip-prinsip analisis wacana, Yogyakarta: Tiara Wacana.

Mahi Hikmat. M. 2009. Efek Berita Politik Media Cetak Pada Perilaku Politik Elit Dalam Pemilu, Tesis (tidak dipublikasikan).

Nasution. 2009. Metode Research, Jakarta: BumiAksara.

Ruslan Ismail Mage. 2013. Berpolitik Dengan Biaya Murah (Solusi Mencegah Politisi Korupsi), Yogyakarta : Studi Investasi Politik Indonesia kerja sama Thafa Media.

Riswandi. 2009. Komunikasi Politik Yogyakarta: Graha Ilmu.

Soerjono Soekanto. 2009. Pengantar Penelitian Hukum. Jakarta: UIPress.

Venus Antar. 2014. Manajemen Kampanye: Panduan Teoritis dan Praktis Dalam Mengefektifkan Kampanye Komunikasi. Bandung: Simbiosa Rekatama Media.
Yasraf A. Piliang. 2005. Transpolitika, Dinamika Politik di Dalam Era Virtualitas. Bandung: Jalasutra.

\section{Website}

Andri Irawan. 07 Juni 2014. Dampak Kampanye Hitam, Jakarta, Sumber : http://www.tempo.co/read/kolom/20 14/06/07/1396/Dampak-KampanyeHitam, diakses 15 Mei 2016.

Aksan. 23 Agustus 2013. Kampanye Hitam Dan Pengaruhnya terhadapa Pemilih, (http://www.wikimu.com/new/Displ ayNews.aspx), diakses pada 14 Mei 2016.

Anasta.http://www2.jawapos.com/baca/art ikel/1573/kampanye-hitam-masihdipakai, diakses pada 15 Mei 2016.

Endy

Bayuni. http://www.jawapos.co.id/read/politi ka/bersihka, pemilu-dari-kampanyehitam, diakses pada 15 Mei 2016.

http://www.republika.co.id/berita/pemilu/ hot-politic/14/07/01-ini-tiga-blackcampaign-yang-serang-jokowi, diakses 10 September 2015.

Mufida.http://www.satuislam.org/opini/pe ngaruh-kampanye-hitam-danpencitraan-politik-dalam-pemilu-diindonesia, diakses pada 15 Mei 2016.

Munajat.

http://www.dw.com/id/kampanyehitam-pengaruhi-pemilih/html, diakses pada 15 Mei 2016. 